\title{
Comparative water balance study of forest and fallow plots
}

\author{
Norbert Móricz ${ }^{(1)}$, Csaba Mátyás ${ }^{(1)}$, Imre Berki ${ }^{(1)}$, Ervin Rasztovits ${ }^{(1)}$, \\ Zoltán Vekerdy ${ }^{(3)}$, Zoltán Gribovszki ${ }^{(2)}$
}

Increasing pressure on groundwater due to land use change (e.g., afforestation) and future climate change will alter the recharge of groundwater aquifers, causing shifts in water table levels and hence influencing the available groundwater resources. The effect of land use change on groundwater resources has initiated a major scientific debate during the last decades between foresters and experts in water management in Hungary and in several other countries. The aim of this study was to compare water balances of two different vegetation covers, a groundwater dependent oak forest and a nearby fallow area in the Hungarian Lowland. Water balance components for an oak and a fallow plots, exposed to similar weather conditions and with similar soils, were estimated and compared by calibrating the Hydrus 1-D model using measured soil water content and groundwater levels. The difference in the groundwater consumption was analyzed in details during dry and wet growing seasons. Transpiration at the fallow plot was only about two-thirds of that in the oak forest, while groundwater consumption was three times higher in the forest than at the fallow plot throughout the two-year study. During the dry growing season, the proportion of groundwater use from the total transpiration reached up to $90 \%$ at the oak plot. According to the model, in the dry growing season in 2007 both vegetation covers relied significantly on groundwater resources, while in 2008 the consumption of groundwater was notably reduced due to the wet weather at both plots.

\section{Keywords: Water Balance, Oak, Fallow, Groundwater Consumption}

\section{Introduction}

The relationship of vegetation cover and groundwater resources has drawn considerable scientific attention over the last decades. Many studies have shown that deforestation by logging or of natural origin (forest fire, wind damage) increased the average runoff from the affected area (e.g., Bosch \& Hewlett 1982) and afforestation decreased runoff. Similar results were detected in recharge rates and groundwater depth, predominantly in dry regions. In Australia changes of vegetation from woodland to grassland or crops resulted in increases in recharge rates of one to two orders of magnitude (Maitre et al 1999). The changes were largely due to the altered interception loss and the increased water extraction from the root zone. However, results of paired watershed research agreed only on the direction of the changes, not on their magnitude (Andressian 2004).

Comparative water balance studies of forest and low vegetation covers have generally shown higher water use of forest cover (Ladekarl et al. 2005, Nachabe et al. 2005 , Schilling 2007). Nachabe et al. (2005) analyzed the groundwater consumption in a shallow water table environment and estimated the annual ET for a forested area (1320 $\mathrm{mm})$ and for a pasture $(700 \mathrm{~mm})$ using de- tailed soil moisture and water table monitoring. At the same time, a few studies have found negligible differences in evapotranspiration of different vegetation covers (e.g., Roberts \& Rosier 2005). The latter study found that, although there were seasonal differences, on an annual basis the drainage below broadleaved woodland did not significantly differ from that below a pasture.

Due to climate change, air temperature is expected to rise significantly during this century (IPCC 2007). As a direct consequence of warmer temperatures, the hydrological cycle will undergo changes with accompanying alteration in the rates of precipitation and evaporation. In Hungary, summer temperatures is expected to increase by up to four degrees by the end of this century, while precipitation is likely to increase in winter and decrease in summer (Gálos et al. 2007).

The impact of climate change on groundwater resources was reviewed lately by Green et al. (2011). Although the uncertainty of predictions for change in groundwater recharge rates and discharge is large (e.g., future climate scenarios and groundwater extraction), numerous studies found that groundwater resources appear to be threatened by future climate change due to increased natural and human water demand.
(1) Institute of Environmental and Earth Sciences, University of West Hungary, Sopron (Hungary); (2) Institute of Geomatics and Civil Engineering, University of West Hungary, Sopron (Hungary); (3) Faculty of Geo-Information Science and Earth Observation (ITC), University of Twente, Enschede (The Netherlands)

@ Norbert Móricz (calvus17@gmail.com)

Received: Nov 19, 2011 - Accepted: Jun 30, 2012

Citation: Móricz N, Mátyás C, Berki I, Rasztovits E, Vekerdy Z, Gribovszki Z, 2012 Comparative water balance study of forest and fallow plots. iForest 5: 188-196 [online 2012-08-02] URL: http://www.sisef.it/ iforest/contents?id=ifor0624-005

Communicated by: Marco Borghetti

In light of the water balance uncertainties and the increasing pressures on groundwater resources due to future climate change, a comparative water balance study of an oak forest and fallow vegetation plots was initiated in a drought-threatened lowland environment in north-eastern Hungary. Water balance components were estimated by the Hydrus 1-D numerical model (Simunek et al. 2005), calibrated on measured soil moisture and groundwater levels.

Our research questions were the following: (1) what is the magnitude of evapotranspiration components in the two different landuses; and (2) how has groundwater consumption evolved during dry and wet growing seasons?

\section{Materials and methods}

\section{Study area}

The study plots are situated in the northeast part of Hungary at latitude $47^{\circ} 58^{\prime} \mathrm{N}$ and longitude $21^{\circ} 42^{\prime} \mathrm{E}$ (Fig. 1), built up from sandy river deposits of the early Pleistocene (Borsy et al. 1981). The climate is continental; the mean annual precipitation (years 1951-2000) is approximately $520 \mathrm{~mm}$ and mean monthly temperature (1951-2000) ranges between $-2.4{ }^{\circ} \mathrm{C}$ in January and 20.5 ${ }^{\circ} \mathrm{C}$ in July.

The plots were located on the discharge area of the local phreatic groundwater flow system with shallow groundwater levels and groundwater supplies from the adjacent areas. Both study plots were selected so that the elevation of the plots above the nearby ditch was almost the same. The generally similar site conditions of the field plots made it possible to compare water balance components and groundwater consumption. The approximately $300 \mathrm{~m}$ distance from the nearby ditch minimized any effect that 
Fig. 1 - Location of the study area.

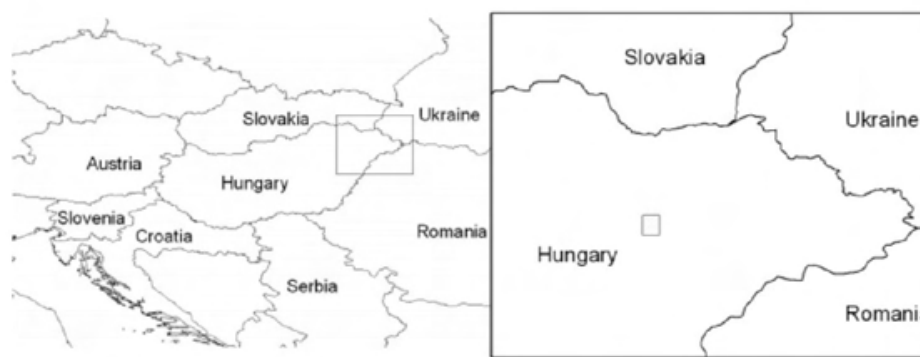

floods had on water table levels. Surface runoff was not observed since the slope of the plots was less than $2 \%$ o (Tab. 1). For detailed description of the oak plot, see Móricz (2010).

The naturally regenerated oak forest had $60 \%$ pedunculate oak (Quercus robur) which are $20-25 \mathrm{~m}$ high and the density is 270 trees ha ${ }^{-1}$. The fallow plot, situated about $3 \mathrm{~km}$ from the oak plot, is part of an agricultural field that had been plowed in the past,

Tab. 1 - Main field-measured, estimated and calibrated parameter values of the oak and fallow plots. (1): Parameters estimated from literature; (d) parameters estimated from database analysis; (Oak): oak plot; (Fallow): fallow plot.

\begin{tabular}{|c|c|c|c|c|}
\hline $\begin{array}{l}\text { Parameter } \\
\text { Class }\end{array}$ & Parameters & Unit & Oak & Fallow \\
\hline $\begin{array}{l}\text { Field- } \\
\text { measured }\end{array}$ & $\begin{array}{l}\text { Height } \\
\text { Maximum LAI } \\
\text { Free throughfall coefficient } \\
\text { Root depth }\end{array}$ & $\begin{array}{l}\mathrm{m} \\
\mathrm{m}^{2} \mathrm{~m}^{-2} \\
\% \\
\mathrm{~m}\end{array}$ & $\begin{array}{c}20-25 \\
3.9 \\
14 \\
1.5\end{array}$ & $\begin{array}{l}0.1-0.2 \\
1.1 \\
- \\
0.8\end{array}$ \\
\hline \multirow[t]{7}{*}{ Estimated } & $\begin{array}{l}\text { Albedo }^{\mathrm{d}} \\
(\text { MODIS data - Justice et al. 2002) }\end{array}$ & $\%$ & $\begin{array}{l}10-16 \\
(75 \text { at snow } \\
\text { cover) }\end{array}$ & $\begin{array}{l}11-17 \\
\text { ( } 45 \text { at snow } \\
\text { cover) }\end{array}$ \\
\hline & $\begin{array}{l}\text { Maximum leaf conductance }{ }^{1} \\
\text { (Federer et al. 1996) }\end{array}$ & $\mathrm{m} \mathrm{s}^{-1}$ & 0.0063 & 0.007 \\
\hline & $\begin{array}{l}\text { Roughness length } \\
\text { (Brutsaert 1982) }\end{array}$ & $\mathrm{m}$ & 0.9 & 0.026 \\
\hline & $\begin{array}{l}\text { Displacement height } \\
\text { (Federer et al. 2003) }\end{array}$ & $\mathrm{m}$ & 15.12 & 0.11 \\
\hline & $\begin{array}{l}\text { Light coefficient of extinction }{ }^{1} \\
\text { (Federer et al. 1996) }\end{array}$ & - & 0.5 & 0.5 \\
\hline & $\begin{array}{l}\text { Stem flow ratio of precipitation } \\
\text { (Valente et al. 1997) }\end{array}$ & $\%$ & 3 & - \\
\hline & $\begin{array}{l}\text { Density } \\
\text { (National Forest Inventory Database 2000) }\end{array}$ & trees $h a^{-1}$ & 270 & - \\
\hline \multirow{8}{*}{ Calibrated } & Canopy storage capacity & $\mathrm{mm}$ & - & - \\
\hline & Vegetation season & - & 1.17 & 1.0 \\
\hline & Dormant season & - & 0.5 & 0.5 \\
\hline & Litter storage capacity & $\mathrm{mm}$ & 0.5 & - \\
\hline & Saturated hydraulic conductivity & $m m$ day $^{-1}$ & - & - \\
\hline & Root-zone & - & $\begin{array}{l}0.9 \times 10^{3} \\
2.9 \times 10^{3}\end{array}$ & $\begin{array}{l}1.5 \times 10^{2} \\
1.1 \times 10^{3}\end{array}$ \\
\hline & Below the root zone & - & $1.4 \times 10^{2}$ & $0.8 \times 10^{2}$ \\
\hline & Readily available specific yield & - & 0.032 & 0.029 \\
\hline
\end{tabular}

but it has not been seeded and cultivated now for several years and is currently under natural succession. The vegetation consists of furrow-weed with species like Solidago gigantea, Artemisia vulgaris, Amaranthus retroflexus and Ambrosia artemisiifolia.

The vertical distribution of the root system was surveyed in situ by taking three replicate volumetric soil core samples at six depths (0-0.2 m, 0.2-0.4 m, 0.4-0.6 m, 0.6-0.8 m, $0.8-1.0 \mathrm{~m}$ and $1.0-1.2 \mathrm{~m}$ ) for both study

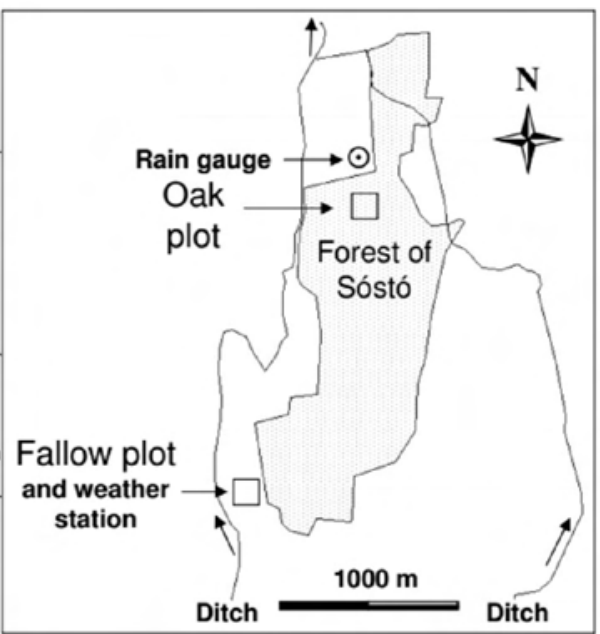

plots. After separating the fine roots (diameter $<2 \mathrm{~mm}$ ) by sieving the soil samples, they were scanned and the total root extent of each sample was determined by grid-counting. Finally, the fine root fraction of each layer was related to the total root extent of the profile. Fine roots reduced approximately linearly with depth at the oak plot (estimated root depth: $1.5 \mathrm{~m}$ ) and logarithmically at the fallow plot (estimated root depth: $0.8 \mathrm{~m}$ ).

Soil analyzes included the sieving and hydrometer analyzes of particle size distribution of the soil samples, taken at $0.2 \mathrm{~m}$ intervals down to a depth of three meters. At both plots the soil texture was compacted fine sand $(0.02-0.2 \mathrm{~mm})$ close to the surface varying between $80-99 \%$. The clay and silt fractions were high below one meter depth at both plots and reach $30-35 \%$ and $20-25 \%$, respectively.

Three repetition of undisturbed soil samples for water retention were analyzed at depths of $0.1,0.3,0.5,0.7,0.9$ and $1.2 \mathrm{~m}$ by cylinders of $100 \mathrm{~cm}^{3}$ (Tab. 2).

The maximum of the Leaf Area Index (LAI $-\mathrm{m}^{2} \mathrm{~m}^{-2}$ ) was estimated by collecting leaf litter on the ground. At the oak plot, newly defoliated leaves were collected carefully from five locations $(1 \times 1 \mathrm{~m})$ during late autumn of 2007 and dried in an oven $\left(105^{\circ} \mathrm{C}\right.$ for 24 hours). Determination of LAI included the calculation of the ratio of weight to leaf area for a subset of leaves and then for the whole sample. The average LAI of the samples was $3.9 \mathrm{~m}^{2} \mathrm{~m}^{-2}$. The 16-day Enhanced Vegetation Index (EVI) product of MODIS (Moderate Resolution Imaging Spectroradiometer) was used to describe the seasonal change of LAI. The $250 \mathrm{~m}$ resolution EVI was converted to LAI using the relationship proposed by Wang et al. (2005).

At the fallow plot, the maximum leaf area index was estimated by leaf collection from three locations $(0.5 \times 0.5 \mathrm{~m})$. All the collected leaves were scanned and the leaf area was determined by grid counting. The mean LAI of the three samples was $1.1 \mathrm{~m}^{2} \mathrm{~m}^{-2}$. The 
same leaf area index was used throughout the vegetation period. During the dormant season, we assumed the LAI $0.5 \mathrm{~m}^{2} \mathrm{~m}^{-2}$, based on the biophysical parameter table of Steyaert \& Knox 2008 - Fig. 2).

The albedo was derived from the 16-day estimates of the MODIS images. The missing values of albedo in winter were assumed as snow cover and were replaced by an albedo of $45 \%$ at the oak and $75 \%$ at the fallow plot (Kondratiev 1969).

\section{Monitoring at the plots}

Meteorological variables, soil water content and groundwater level were monitored by automatic equipment.

A weather station (iMETOS, Pessl Instruments, Austria) at the fallow plot and an automatic rain-gauge (Rainlog Data Logger, Rainwise, USA) $500 \mathrm{~m}$ apart from the oak plot were employed to monitor weather conditions (Fig. 1). The time resolution of rain measurements was 1 minute, while all other variables were recorded hourly.

The volumetric water content was monitored with FDR (Frequency Domain Reflectometers) using Decagon EC-5 probes (Decagon Devices, Pullman, USA) with a time interval of $15 \mathrm{~min}$. The probes were installed at depths of $0.1,0.3,0.5$ and $0.7 \mathrm{~m}$.

Groundwater level was measured by a Dataqua DA-S-LRB 118 vented pressure transducer (Dataqua Elektronikai Kft. Balatonalmádi, Hungary) with time interval of 15 min. Manual groundwater level measurements were used to verify the reliability of the monitoring.

Water balance modeling with Hydrus 1D

\section{Model structure}

The Hydrus 1-D (Simunek et al. 2005) model was applied for the estimation of soil water content changes, actual transpiration and soil surface evaporation at both plots. Hydrus 1-D is a modeling software for analysis of water flow and solute transport in variably saturated porous media. The base of the model is the variable saturated vertical flow domain, where water flow is simulated.

The soil depth was set to three meters at both plots and was partitioned into seven soil layers according to the soil sampling ( 0 $20 \mathrm{~cm}, 20-40 \mathrm{~cm}, 40-60 \mathrm{~cm}, 60-80 \mathrm{~cm}, 80-$ $100 \mathrm{~cm}, 100-120 \mathrm{~cm}, 120-300 \mathrm{~cm})$. The Hydrus model computed the variables of water flow for 200 soil horizons with gradually increments by depth. During the modeling daily time steps were used.

Daily potential transpiration $T_{\mathrm{P}}\left(\mathrm{mm}\right.$ day $\left.^{-1}\right)$ and evaporation $E_{\mathrm{P}}\left(\mathrm{mm}\right.$ day $\left.^{-1}\right)$ values together with the effective precipitation $P_{\mathrm{EFF}}(\mathrm{mm}$ day $\left.^{-1}\right)$ constitute the upper boundary condition of the model. $P_{\mathrm{EFF}}$ is the difference between the gross precipitation $\left(\mathrm{mm}\right.$ day $\left.^{-1}\right)$

Tab. 2 - Mean of the three measured water retention data of the plots at six depths for five pressure heads. (Oak): Oak plot; (Fall): Fallow plot.

\begin{tabular}{|c|c|c|c|c|c|c|c|c|c|c|c|c|}
\hline \multirow{3}{*}{ Pressure } & \multicolumn{12}{|c|}{ Water content $(\%)$} \\
\hline & \multicolumn{2}{|c|}{$10 \mathrm{~cm}$} & \multicolumn{2}{|c|}{$30 \mathrm{~cm}$} & \multicolumn{2}{|c|}{$50 \mathrm{~cm}$} & \multicolumn{2}{|c|}{$70 \mathrm{~cm}$} & \multicolumn{2}{|c|}{$90 \mathrm{~cm}$} & \multicolumn{2}{|c|}{$120 \mathrm{~cm}$} \\
\hline & Oak & Fall & Oak & Fall & Oak & Fall & Oak & Fall & Oak & Fall & Oak & Fall \\
\hline$-1 \mathrm{~cm}$ & 52.7 & 34.4 & 42.5 & 38.4 & 48.5 & 39.4 & 46.9 & 39.7 & 37.9 & 38.3 & 37.0 & 37.2 \\
\hline$-10 \mathrm{~cm}$ & 42.8 & 32.6 & 39.0 & 35.0 & 39.7 & 35.6 & 39.9 & 36.7 & 36.0 & 37.7 & 35.6 & 36.8 \\
\hline$-333 \mathrm{~cm}$ & 20.2 & 19.4 & 20.1 & 19.3 & 17.8 & 23.7 & 22.5 & 30.3 & 32.3 & 30.5 & 23.4 & 33.9 \\
\hline$-1000 \mathrm{~cm}$ & 16.7 & 15.1 & 16.0 & 14.5 & 15.5 & 18.3 & 18.0 & 22.0 & 25.9 & 22.7 & 16.8 & 26.4 \\
\hline$-15000 \mathrm{~cm}$ & 7.8 & 10.4 & 7.9 & 9.3 & 7.5 & 11.9 & 7.3 & 14.0 & 14.1 & 14.0 & 9.6 & 17.4 \\
\hline
\end{tabular}

and the interception loss (mm day ${ }^{-1}$ - Fig. 3$)$.

The net groundwater supply $Q_{\mathrm{NET}}$ (mm day $^{-1}$ ) defined the water flux at the lower boundary of the soil profile, which was computed using the high-frequency groundwater level data and the readily available specific yield $S_{\mathrm{y}}$.

Water retention parameters and saturated hydraulic conductivity $k_{\mathrm{s}}\left(\mathrm{mm}\right.$ day $\left.^{-1}\right)$ were put into the Hydrus 1D program for each soil layers. The RETC software (van Genuchten et al. 1991) was employed to get the soil water retention parameters from pairs of water content and pressure head data (van Genucthen 1980). Saturated hydraulic conductivity of the root zone was estimated for every soil layer using the method of Rawls et al. (1998), although the final values were set by calibration. Root density was assigned to the profile based on field observations.

The actual values of transpiration $T$ and soil surface evaporation $E$ was computed using the potential values, soil hydraulic parameters, the available water content and the root density by the Hydrus 1-D model.

\section{Effective precipitation}

Effective precipitation was computed by estimation of the canopy and litter intercep-

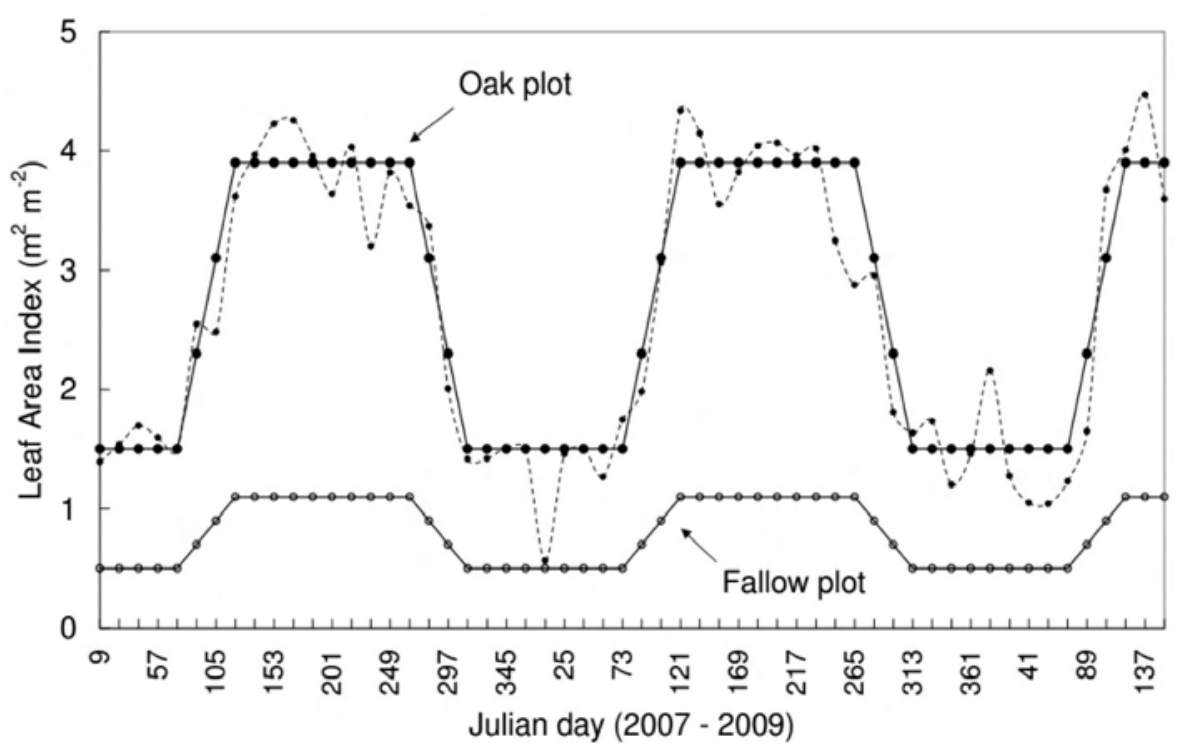

Fig. 2 - Seasonal change of LAI (Oak plot: dashed line - MODIS data, solid line - applied). tion loss at the oak plot. The canopy interception loss was calculated applying the Gash model in the growing season (for details, see Gash 1979). Besides the growing posed by Menzel (1997) was used to estimate canopy interception loss. The method applies the daily sum of precipitation, the leaf area index and two species-specific parameters, describing the relation between LAI and the storage capacity (Wattenbach et al. 2005) and the slope of the saturation curve (Otto 1994).

Litter storage capacity was set during the model calibration.

Interception loss $I$ was computed by a daily interception method at the fallow plot (von Hoyningen-Hüne 1983 - eqn. 1):

$$
I=a_{i} L A I\left(1-\frac{1}{1+\frac{b P}{a_{i} L A I}}\right)
$$

where $b$ is the soil cover fraction, which was set to unity since the soil surface was completely covered by vegetation. The empirical parameter $a_{\mathrm{i}}$ denotes the storage capacity of the vegetation by multiplying with the $L A I$ season, the daily interception method, pro- 


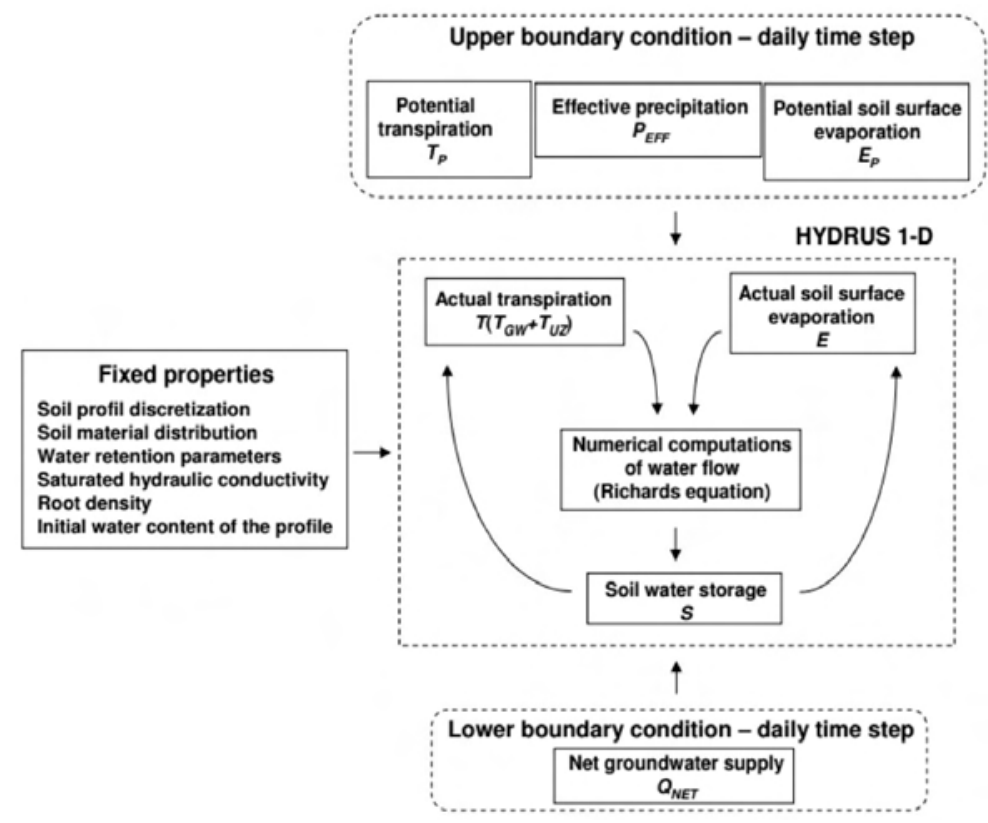

Fig. 3 - Structure of the model. $\left(P_{\mathrm{EFF}}\right)$ : effective precipitation; $\left(T_{\mathrm{P}}\right)$ : potential transpiration; $(T)$ : actual transpiration; $\left(T_{\mathrm{GW}}\right)$ : groundwater consumption; $\left(T_{\mathrm{UZ}}\right)$ : transpiration from the unsaturated zone; $\left(E_{\mathrm{P}}\right)$ : potential soil surface evaporation; $(E)$ : actual soil surface evaporation; $\left(Q_{\mathrm{NET}}\right)$ net groundwater supply; $(S)$ : soil water storage. All components are in mm day ${ }^{-1}$.

$\left(\mathrm{m}^{2} \mathrm{~m}^{-2}\right)$ and $P$ is the daily sum of precipitation $\left(\mathrm{mm} \mathrm{day}^{-1}\right)$.

\section{Potential transpiration and soil surface evaporation}

Potential transpiration $T_{\mathrm{P}}$ was defined as the canopy transpiration rate, when not limited by soil water deficits (Monteith 1965 eqn. 2):

$$
T_{p}=\frac{\Delta(K+L)+\rho_{a} c_{a} C_{a t} V P D}{\rho_{w} \lambda_{v}\left[\Delta+\gamma\left(1+C_{a t} / C_{c a n}\right)\right]}
$$

where $T_{\mathrm{P}}$ is the potential transpiration ( $\mathrm{mm}$ day $\left.^{-1}\right), K$ is the net shortwave radiation (MJ $\mathrm{m}^{-2}$ day $\left.^{-1}\right), L$ is the net longwave radiation $\left(\mathrm{MJ} \mathrm{m}^{-2}\right.$ day $\left.^{-1}\right), \Delta$ is the slope of the saturation vapor pressure curve $\left(\mathrm{kPa}^{\circ} \mathrm{C}^{-1}\right), \gamma$ is the psychrometric constant $\left(\mathrm{kPa}^{\circ} \mathrm{C}^{-1}\right), V P D$ is the vapor pressure deficit $(\mathrm{kPa}), \rho_{\mathrm{a}}$ is the air density $\left(\mathrm{kg} \mathrm{m}^{-3}\right), c_{\mathrm{a}}$ is the specific heat of moist air $\left(\mathrm{kJ} \mathrm{kg}^{-1}{ }^{\circ} \mathrm{C}^{-1}\right), \lambda_{v}$ is the latent heat of vaporization $\left(\mathrm{MJ} \mathrm{kg}^{-1}\right), \rho_{\mathrm{w}}$ is the specific heat of air $\left(\mathrm{kJ} \mathrm{kg}^{-1}{ }^{\circ} \mathrm{C}^{-1}\right), C_{\text {at }}$ is the aerodynamic conductance $\left(\mathrm{m} \mathrm{s}^{-1}\right)$ and $C_{\text {can }}$ is the canopy conductance $\left(\mathrm{m} \mathrm{s}^{-1}\right)$. $C_{\text {can }}$ was computed by multiplying the leaf area index by leaf conductance $\left(\mathrm{m} \mathrm{s}^{-1}\right)$.

Leaf conductance $C_{\text {leaf }}\left(\mathrm{m} \mathrm{s}^{-1}\right)$ was estimated after Jarvis (1976) to express the effect of atmospheric demand on stomatal opening (eqn. 3):

$$
C_{\text {leaf }}=g_{l \min }+f_{T} f_{D} f_{R} f_{W} f_{c}\left(g_{l \max }-g_{l \min }\right)
$$

where $g_{\mid \max }$ and $g_{\operatorname{lmin}}$ are the maximum and minimum leaf conductance $\left(\mathrm{m} \mathrm{s}^{-1}\right)$, respec- tively, and $f_{\mathrm{T}}, f_{\mathrm{D}}, f_{\mathrm{R}}, f_{\mathrm{W}}, f_{\mathrm{C}}$ are reduction factors, varying between zero and unity, that account for effects of temperature, vapor pressure deficit, radiation, leaf water stress and atmospheric carbon dioxide concentration on stomatal opening.

The reduction factors $f_{\mathrm{T}}$ and $f_{\mathrm{D}}$ were computed after Federer et al. (1996) and Lohammar et al. (1980). The radiation response $f_{\mathrm{R}}$ was estimated after Stewart (1988) using the measured global radiation. The leaf water stress was omitted, thus $f_{\mathrm{W}}=1$, and the effect of changing atmospheric carbon dioxide was also not considered, so $f_{\mathrm{C}}=1$.

Potential soil surface evaporation $E_{\mathrm{P}}$ was also computed by the Penman-Monteith equation, based on the net radiation which reaches the soil surface (Ritchie 1972).

\section{Net groundwater supply}

Diurnal fluctuation of groundwater levels occurs in shallow groundwater regions. The main inducing factor is the diurnal changes of transpiration during vegetation periods (Gribovszki et al. 2010).

Gribovszki et al. (2008) developed an empirical approach, based on the White-method (White 1932) using the observed groundwater level data and the readily available specific yield $S_{\mathrm{y}}$. The primary assumption was that $Q_{\text {net }}$ displays a significant daily variation due to hydraulic gradient changes over the day. The maximum value of $Q_{\text {net }}$ was calculated for each day by selecting the largest positive time-rate of change value in the groundwater level readings, while the minimum was obtained by computing the mean of the smallest time-rate of change in the predawn hours, by multiplying it by the value of $S_{\mathrm{y}}$ (eqn. 4):

$$
Q_{N E T}=S_{y} \frac{d h}{d t}
$$

where $Q_{\mathrm{NET}}$ is the net groundwater supply, $h$ is the groundwater level, $t$ is the time and $S_{\mathrm{y}}$ is the readily available specific yield.

The values of the minimum and maximum $Q_{\text {net }}$ then were assigned to the locations of the groundwater level extremes. Spline interpolation was applied to interpolate the missing values between the minimum and maximum values. The daily sum of the net groundwater supplies was computed by summing up the half-hourly values.

Readily available specific yield was introduced by Meyboom (1967) to denote the amount of water that can be released from the vadose zone during the time-frame of the daily fluctuations. $S_{y}$ was estimated from soil texture data using the diagram of Loheide II et al. (2005). The final values were set during the calibration of the model.

\section{Actual transpiration and soil surface eva- poration}

Actual transpiration $T$ was computed by integrating the actual transpiration rates of all model layers by the Hydrus 1-D model (Simunek et al. 2005). The actual transpiration rate of a specific model soil layer is (eqn. 5):

$$
T_{m s l}=\alpha(h) S_{p}
$$

where $T_{\mathrm{msl}}$ is the actual transpiration of one specific model soil layer, $\alpha(h)$ is the value of the $S$-shaped water uptake response function (van Genuchten 1987) and $S_{\mathrm{p}}$ is the potential uptake rate of that soil layer $\left(\mathrm{mm} \mathrm{day}^{-1}\right)$, determined by the vertical root distribution.

Values of the parameter $\alpha(h)$ may be obtained as follows (eqn. 6):

$$
\alpha(h)=\frac{1}{1+\left(\frac{h}{h_{50}}\right)^{p}}
$$

where $h$ is the pressure head $(\mathrm{cm}), h_{50}$ represents the pressure head at which the water extraction rate is reduced by $50 \%(\mathrm{~cm})$ and $p$ is an experimental constant. The latter was set to three after van Genuchten (1987) and $h_{50}$ was set to $-4300 \mathrm{~cm}$ (Cardon \& Letey 1992).

$S_{\mathrm{p}}$ is calculated using the value of daily potential transpiration and the normalized root water uptake distribution. For more details see Simunek et al. (2005).

Actual soil surface evaporation $E$ was estimated by the Hydrus model, based on soil water conditions and soil hydraulic properties using Darcy's Law, bounded by the po- 
tential soil surface evaporation.

\section{Model calibration}

The observed soil water content and groundwater level data were employed to calibrate the Hydrus model at both plots. The model was calibrated specifically for this two year period and not used for future simulation.

During the model calibration, the storage capacity of vegetation and soil hydraulic parameters were modified to reduce the deviations between the modeled and observed soil water content of each layer and groundwater level.

At the oak plot, first the interception loss of the dormant season was calibrated. The storage capacity of stems and branches was set to $0.5 \mathrm{~mm}$ (Larcher 1994). Litter storage capacity was generally set to $0.5 \mathrm{~mm}$. Storage capacity of the canopy in the vegetation period was calibrated to $1.17 \mathrm{~mm}$ at the maximum LAI $3.9 \mathrm{~m}^{2} \mathrm{~m}^{-2}$. A similar result (1.19 $\mathrm{mm}$ ) was obtained by André et al. (2008) in an oak dominated stand (LAI $=3.8 \mathrm{~m}^{2} \mathrm{~m}^{-2}$ ).

In the fallow plot, the best fit with the observed soil moisture was achieved by using a storage capacity of $1.0 \mathrm{~mm}$ during the vegetation period and $0.5 \mathrm{~mm}$ for the period of the dormant season.

During the calibration of the saturated hydraulic conductivity, the initially computed values were modified for the root-zone $(<1.5$ $\mathrm{m}$ at the oak and $<0.8 \mathrm{~m}$ at the fallow plot) of the soil profile. The calibrated $k_{\mathrm{s}}$ values changed between $2.9 \cdot 10^{3} \mathrm{~mm}^{3}$ day $^{-1}$ in the upper most horizon and $0.9 \cdot 10^{3} \mathrm{~mm} \mathrm{day}^{-1}$ at about $1 \mathrm{~m}$ depth at the oak plot. In the saturated zone, the calibrated $k_{\mathrm{s}}$ value was around $1.4 \cdot 10^{2} \mathrm{~mm} \mathrm{day}^{-1}$ (Tab. 1)

At the fallow plot, the calibrated $k_{\mathrm{s}}$ values varied from $1.5 \cdot 10^{2} \mathrm{~mm}^{-1 a y^{-1}}$ to $1.1 \cdot 10^{3}$ $\mathrm{mm}$ day $^{-1}$ in the root zone and around $0.8 \cdot 10^{2} \mathrm{~mm}^{-1}$ day $^{-1}$ below the root zone.

Readily available specific yield was calibrated to 0.032 at the oak and to 0.029 at the fallow plot.

\section{Model performance}

The calibrated soil water content and groundwater levels were compared with measured values at both plots to check the performance of the model. The performance criteria were the coefficient of determination $R^{2}$, the root mean square error $R M S E$ and the Nash-Sutcliffe modeling efficiency $M E$.

\section{Results and discussion}

Comparison of observed and modeled results

The calibrated soil water contents compared well with observations at both plots (Fig. 4).
The discrepancies at the beginning of the growing season of 2007 in measured vs. modeled soil water content may be attributed to the disturbance of the soil profile and vegetation at both plots during installation of the monitoring equipment. There were deviations at the fallow plot at a depth of 10 cm in December 2008 and January 2009, due to strong soil water freezing.

The calibrated groundwater levels compared quite well with measurements at both plots. Due to a malfunction of the pressure transducer, the continuous measurement failed at the fallow plot between November 2007 and June 2008. During this period regular manual groundwater depth measurements were employed to follow groundwater levels at the fallow plot (Fig. 5).

Tab. 3 presents the results of the performance criteria.

Comparison of the measured and calibrated soil water content and groundwater levels showed no systematic divergence at the plots (Fig. 6).

\section{Water balance results}

Total rainfall interception was twice as much in the forest than at the fallow plot considering the whole study period. In the 2007 growing season, 38\% of the rainfall was intercepted at the oak plot, while at the fallow plot it was only $15 \%$ of the gross
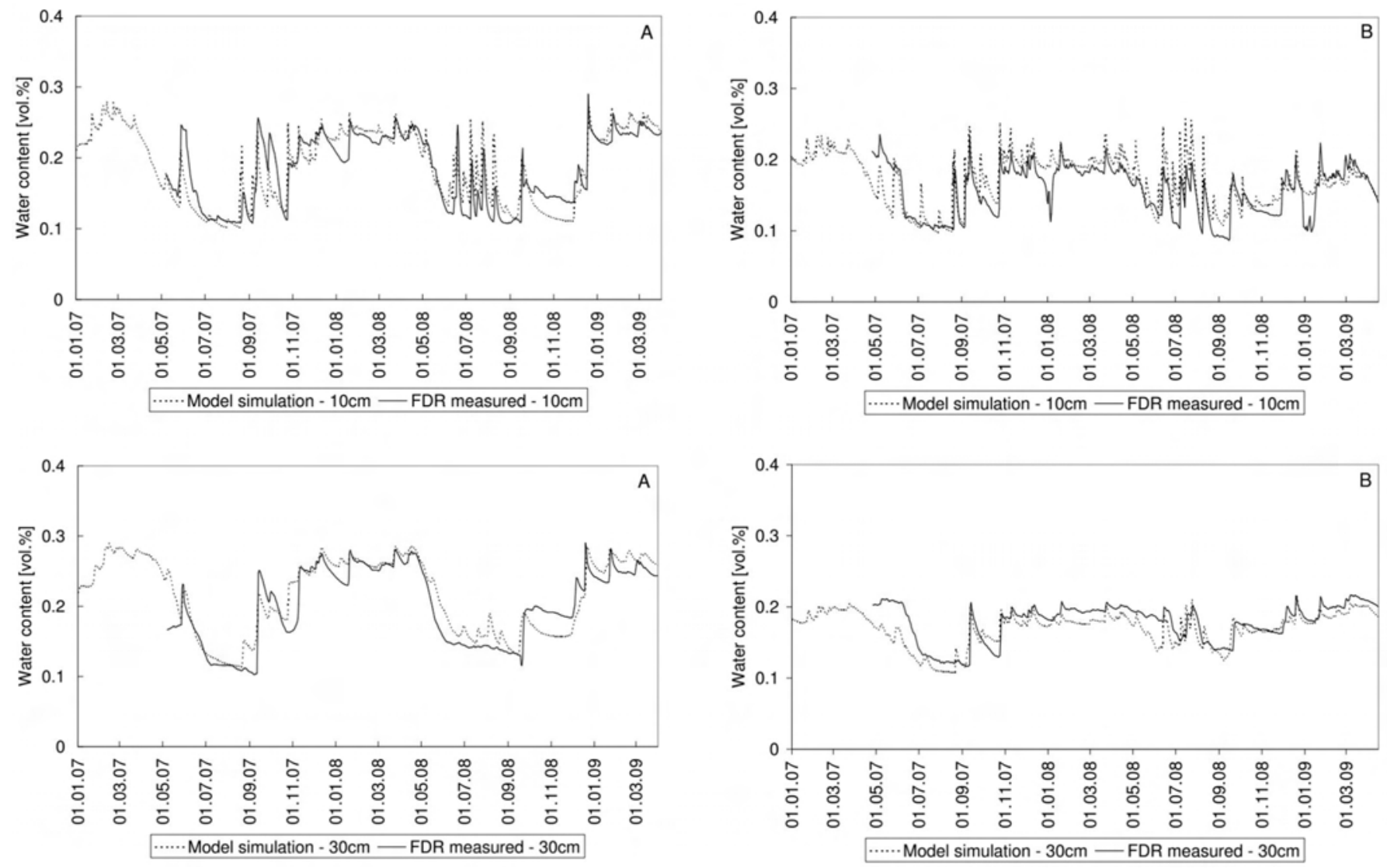

Fig. 4 - Comparison of measured and calibrated soil water contents at the oak (A) and fallow (B) plots. 

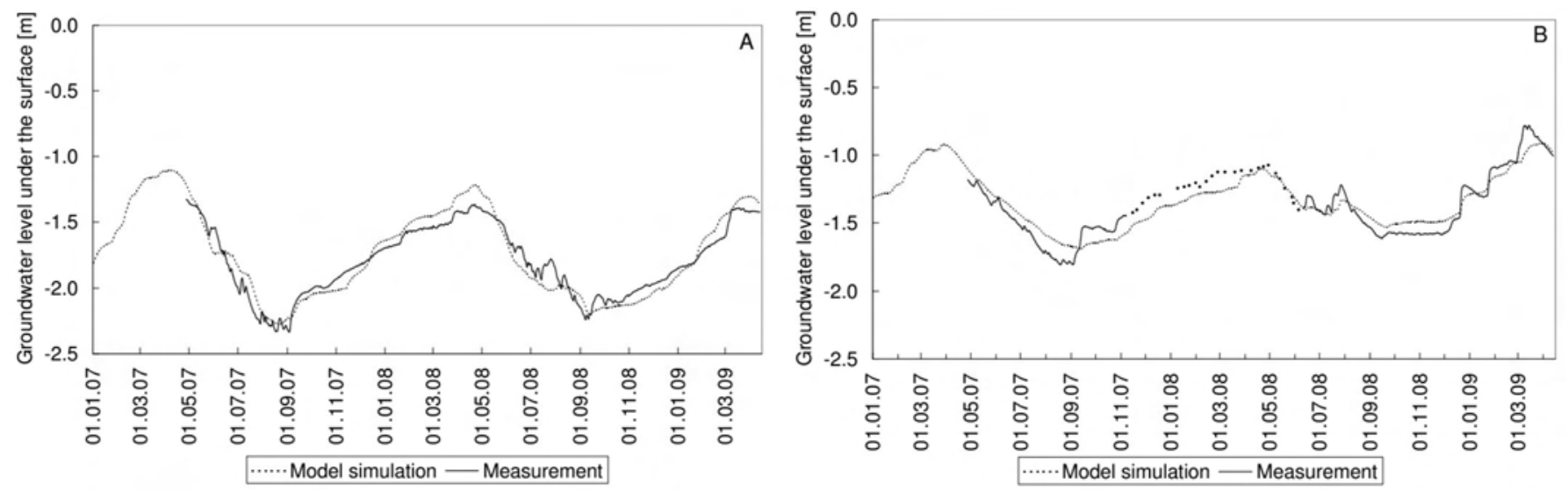

Fig. 5 - Comparison of measured and calibrated groundwater levels at the oak (A) and fallow (B) plots.
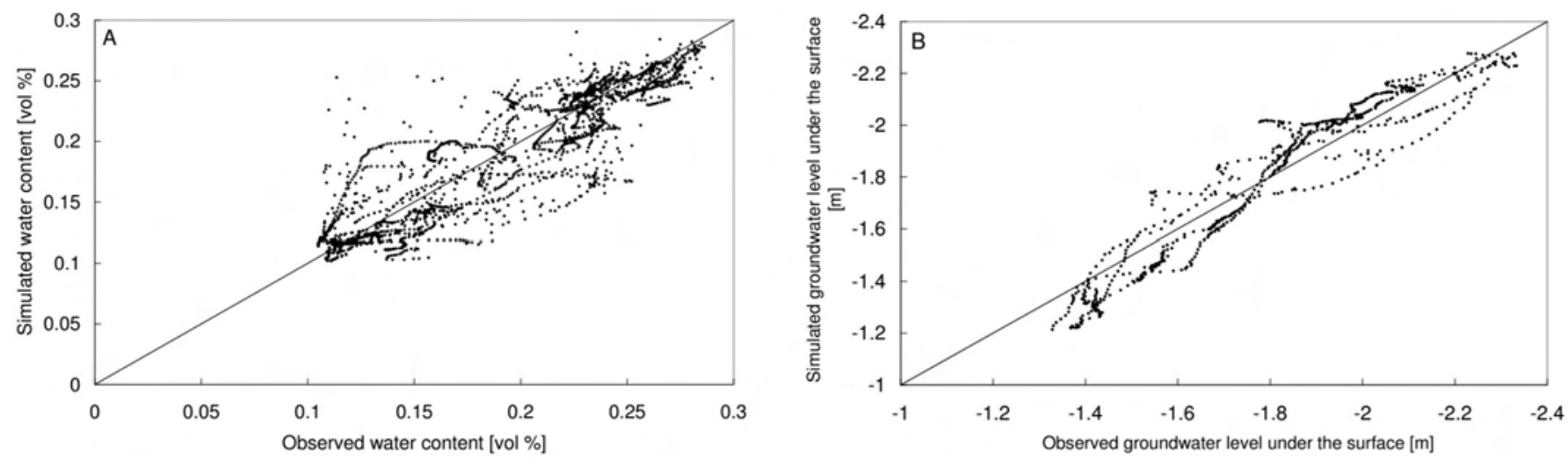

Fig. 6 - Comparison of the daily observed and calibrated soil moisture contents (A) and daily groundwater levels (B) at the oak plot.

rainfall. As a consequence of more rainfall in 2008 , the ratio of interception loss to precipitation decreased slightly at both plots.

According to the Hydrus model, the oak forest transpired approximately 33\% more than the fallow vegetation, while groundwater consumption was three times higher during the study period.

Actual soil surface evaporation was only $4 \%$ of the total evapotranspiration at the oak plot, and $26 \%$ at the fallow plot during the whole study period. The low evaporation amount of the oak plot was the consequence of the high surface resistance due to the litter layer and the shading effect of the canopy. Available net radiation at the soil surface, and soil surface evaporation rates were higher at the fallow plot; thus the soil surface dried out more rapidly than at the oak plot.

Since weather conditions were quite contrasting during the growing seasons of 2007 and 2008 , we decided to compare the water balances for both plots from $1^{\text {st }}$ of April until $30^{\text {th }}$ of September.

Groundwater consumption $T_{\mathrm{GW}}$ was computed using the temporal changes of the capillary fringe in the Hydrus model results, which was $66 \%$ of the total transpiration at the oak plot, while at the fallow plot it was only $38 \%$ in the growing season of 2007 (Fig. 7).

In this growing season, the water uptake

Tab. 3 - Model performance criteria for soil water content and groundwater levels.

\begin{tabular}{llccc}
\hline Plot & Criteria & $\mathbf{R}^{2}$ & RMSE\% & ME \\
\hline Oak Plot & Soil water content $(10 \mathrm{~cm})$ & 0.727 & 14.91 & 0.690 \\
& Soil water content $(30 \mathrm{~cm})$ & 0.830 & 11.95 & 0.796 \\
& Soil water content $(50 \mathrm{~cm})$ & 0.787 & 13.52 & 0.769 \\
& Groundwater level & 0.921 & 5.03 & 0.883 \\
\hline Fallow Plot & Soil water content $(10 \mathrm{~cm})$ & 0.577 & 16.01 & 0.473 \\
& Soil water content $(30 \mathrm{~cm})$ & 0.667 & 10.83 & 0.472 \\
& Soil water content $(70 \mathrm{~cm})$ & 0.828 & 9.83 & 0.782 \\
& Groundwater level & 0.883 & 5.11 & 0.872 \\
\hline
\end{tabular}

showed the effect of drought in summer. Until the start of the summer, the transpiration from the unsaturated zone $T_{\mathrm{UZ}}$ was considerable from the total transpiration. The fraction of groundwater consumption increased to $60 \%$ at the fallow and to $90 \%$ at the oak plot in summer.

In the growing season of 2008 rainy weather provided a considerable amount of moisture for the unsaturated zone; thus the groundwater consumption was reduced from the preceding year. Groundwater consumption at the oak plot was $50 \%$ of the total transpiration, while at the fallow plot it was $25 \%$ in the growing season of 2008 (Fig. 8).

While in the growing season of 2007 both vegetation covers relied significantly on groundwater resources, in 2008 the evapotranspiration loss of groundwater was reduced considerably due to the rainy weather at both plots.

The water balance components of the growing seasons of 2007 and 2008 are shown in Tab. 4.

A meteorological tower was not set up at the oak plot, which contributed to the deviations of modeling results from the measurements. Air temperature and relative hu- 

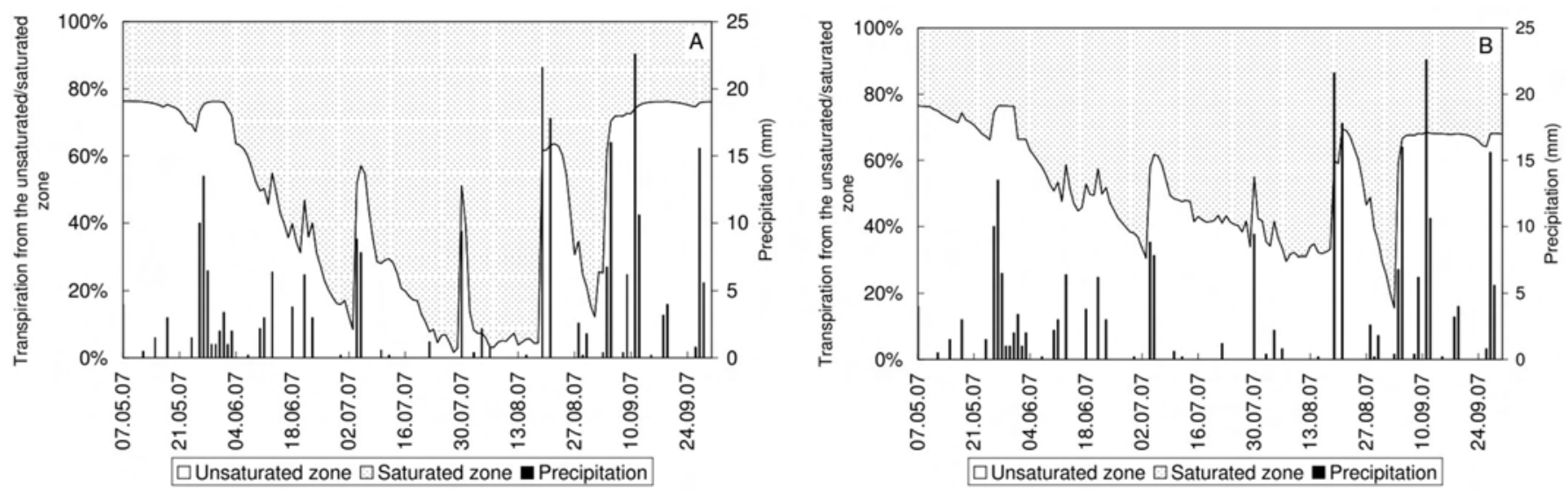

Fig. 7 - Proportion of the water uptake from the unsaturated and saturated zone and precipitation at the oak (A) and at the fallow (B) plots during the growing season 2007.
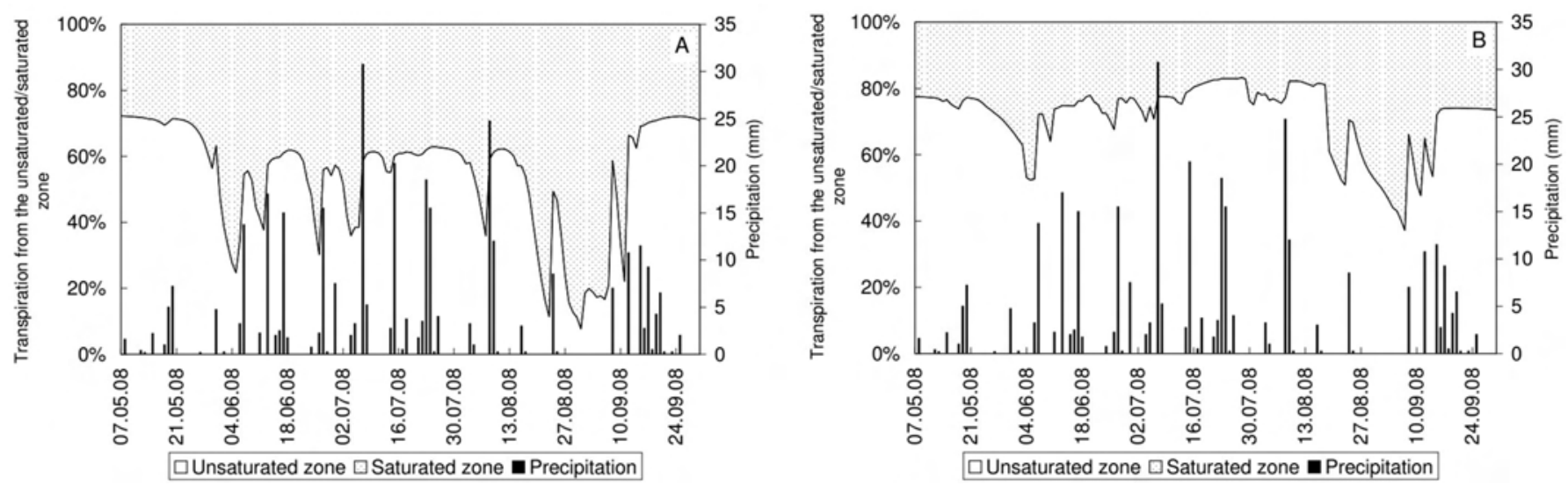

Fig. 8 - Proportion of the water uptake from the unsaturated and saturated zones and precipitation at the oak (A) and at the fallow (B) plots during the growing season of 2008 .

midity at the fallow plot were applied above the canopy of the oak forest, which had an influence on the computation of potential transpiration and evaporation.

The empirical approach for computing $Q_{\mathrm{NET}}$ is further source of uncertainty, since it is sensitive to the quality, the time-step of the record of groundwater levels and the readily available specific yield. The groundwater level data was carefully examined and suspicious measurements were not considered for further computation. The time-

Tab. 4 - Water balance components (mm) of the growing seasons of 2007 and 2008 at the oak and fallow plots.

\begin{tabular}{lcccc}
\hline \multirow{2}{*}{ Water balance components } & \multicolumn{3}{c}{ Growing season - 2007 } & Growing season - 2008 \\
\cline { 2 - 5 } & Oak plot & Fallow plot & Oak plot & Fallow plot \\
\hline Precipitation $(P)$ & 261 & 261 & 383 & 401 \\
Interception loss $(I)$ & 95 & 39 & 129 & 50 \\
Soil surface evaporation $(E)$ & 22 & 139 & 41 & 154 \\
Transpiration from unsaturated zone $\left(T_{\mathrm{UZ}}\right)$ & 208 & 235 & 255 & 260 \\
Groundwater consumption $\left(\mathrm{T}_{\mathrm{GW}}\right)$ & 405 & 144 & 255 & 87 \\
Net groundwater supply $\left(Q_{\mathrm{NET}}\right)$ & 289 & 125 & 184 & 55 \\
Change of soil water storage $(S)$ & -180 & -171 & -112 & -95 \\
\hline
\end{tabular}

step for calculation of $Q_{\mathrm{NET}}$ was half an hour, considering the 15 min frequency of groundwater level readings, suggested by Gribovszki et al. (2008). The final value of the readily available specific yield was set to constant despite of its inherent variable nature in space and time.

\section{Conclusions}

Water balance components of an oak and fallow plot were estimated from April $1^{\text {st }}$ 2007 to April $1^{\text {st }} 2009$ by calibrating the Hy- drus 1-D model using soil moisture and groundwater level measurements. The study period included a dry (2007) and a wet growing season (2008).

For the entire study period, the Hydrus 1-D model results have shown that the total transpiration of the fallow plot was only two thirds of that obtained in the oak plot, while the soil surface evaporation in the oak plot was approximately one fifth of that in the fallow plot. The separation of transpiration into unsaturated transpiration and groundwater consumption has revealed that the groundwater consumption at the oak plot was almost three times higher than at the fallow plot. The groundwater consumption was close to $60 \%$ of the total transpiration at the oak forest and approximately $30 \%$ at the fallow plot.

By comparing the dry (2007) and wet (2008) growing seasons, we found that groundwater consumption was approximately $40 \%$ less in the wet than in the drier growing season, despite the fact that the groundwater level was deeper during the dry 
period. Thus, during the dry season both vegetation covers relied considerably on the available groundwater resources.

The results obtained of this investigation reinforce previous reports on higher groundwater consumption of forests as compared to other vegetation covers. Therefore, future afforestation in arid regions with shallow groundwater levels should pay attention to the large groundwater depleting effect of forests, especially in light of future climate change and human water extraction.

\section{Acknowledgments}

This research was funded by National $\mathrm{R}+\mathrm{D}$ (NKFP 3B/2002/012 and NKFP 6-47/2005), EU Joint Development (TÁMOP-4.2.2-08/12008-0020 and TÁMOP 4.2.2.B-10/1-20100018 "Talentum") projects and the HAS Bolyai scholarship. The authors would also like to acknowledge NASA for providing the MODIS data free of charge, and anonymous reviewers for providing input to improve the quality of the manuscript.

\section{References}

André F, Jonard M, Ponette Q (2008). Precipitation water storage capacity in a temperate mixed oak-beech canopy. Hydrological Processes 22 (20): 4130-4141. - doi: 10.1002/hyp.v22:20

Andressian V (2004). Waters and forests: from historical controversy to scientific debate. Journal of Hydrology 291: 1-27. - doi: 10.1016/j.jhydrol.2003.12.015

Borsy Z, Csongor É, Sárkány S, Szabó I (1981). Phases of blown-sand movements in the NorthEast part of the Great Hungarian Plain. Acta geographica ac geologica et meteorologica, Debrecina 20: 5-33.

Bosch JM, Hewlett JD (1982). A review of catchment experiments to determine the effect of vegetation changes on water yield and evapotranspiration. Journal of Hydrology 55: 3-23. - doi: 10.1016/0022-1694(82)90117-2

Brutsaert W (1982). Evaporation into the atmosphere: theory, history, and applications. D. Reidel, Hingham MA, USA, pp. 299.

Cardon GE, Letey J (1992). Plant water uptake terms evaluated for soil water and solute movement models. Soil Science Society of America Journal 56 (6): 1876-1880. - doi: 10.2136/sssaj1992.03615995005600060038x

Federer CA, Vörösmarty C, Fekete B (1996). Intercomparison of methods for calculating potential evaporation in regional and global water balance models. Water Resources Research 32 (7): 2315-2321 - doi: 10.1029/96WR00801

Federer CA, Vörösmarty C, Fekete B (2003). Sensitivity of annual evaporation to soil and root properties in two models of contrasting complexity. Journal of Hydrometeorology 4: 1276-1290. - doi: 10.1175/1525-7541(2003)004<1276:SOA $\mathrm{ETS}>2.0 . \mathrm{CO} ; 2$

Gash JHC (1979). An analytical model of rainfall interception by forests. Quarterly Journal of the Royal Meteorological Society 105: 43-45. - doi: 10.1002/qj.49710544304

Gálos B, Lorenz PH, Jacob D (2007). Will dry events occur more often in Hungary in the future? Environmental Research Letters 2: 034006. - doi: 10.1088/1748-9326/2/3/034006

Green TR, Taniguchi M, Kooi H, Gurdak JJ, Allen DM, Hiscock KM, Treidel H, Aureli A (2011). Beneath the surface of global change: Impacts of climate change on groundwater. Journal of Hydrology 405: 532-560. - doi: 10.1016/j.jhydrol.2011.05.002

Gribovszki Z, Kalicz P, Szilágyi J, Kucsara M (2008). Riparian zone evapotranspiration estimation from diurnal groundwater level fluctuations. Journal of Hydrology 349: 6-17. - doi: 10.1016/ j.jhydrol.2007.10.049

Gribovszki Z, Szilagyi J, Kalicz P (2010). Diurnal fluctuations in shallow groundwater levels and streamflow rates and their interpretation - A review. Journal of Hydrology 385 (1-4): 371-383. doi: 10.1016/j.jhydrol.2010.02.001

IPCC (2007). Climate change 2007: synthesis report. Contribution of Working Groups I, II and III to the Fourth Assessment Report of the Intergovernmental Panel on Climate Change, Geneva, Switzerland. [online] URL: http//:www.ipcc.ch Jarvis PG (1976). The interpretation of the variations in leaf water potential and stomatal conductance found in canopies in the field. Phil Trans Royal Soc Lond B 273 (927): 593-610. doi: 10.1098/rstb.1976.0035

Justice CO, Townshend JRG, Vermote EF, Masuoka E, Wolfe RE, El-Saleous N, et al. (2002). An overview of MODIS land data processing and product status. Remote Sensing of Environment 83: 3-15. - doi: 10.1016/S0034-4257(02) 00084-6

Kondratiev KY (1969). Radiation in the atmosphere. Academic Press, New York, USA.

Ladekarl UL, Rasmussen KR, Christensen S, Jensen KH, Hansen B (2005). Groundwater recharge and evapotranspiration for two natural ecosystems covered with oak and heather. Journal of Hydrology 300: 76-99. - doi: 10.1016/ j.jhydrol.2004.05.003

Larcher W (1994). Ökophysiologie der Pflanzen. Verlag Eugen Ulmer, Stuttgart, Germany.

Lohammar T, Larsson L, Linder S, Falk SO (1980). FAST - simulation models of gaseous exchange in Scots pine. In: "Structure and function of northern coniferous forests" (Persson T ed). Ecological Bulletins 32: 505-523.

Loheide II SP, Butler JJ, Gorelick SM (2005). Estimation of groundwater consumption by phreatophytes using diurnal water table fluctuations: a saturated-unsaturated flow assessment. Water Resources Research 41: W07030. - doi: 10.1029/2005WR003942

Maitre DCL, Scott DF, Colvin C (1999). A review of information on interactions between vegetation and groundwater. Water South Africa 25: 137-152. [online] URL: http://researchspace.csir.co.za/dspace/bitstream/10204/524/1/Le\%20maitre\%20 1999.pdf

Menzel L (1997). Modellierung der Evapotranspiration im System Boden-Pflanze-Atmosphäre.
Züricher Geographische Schriften, Heft 67, Geographisches Institut ETH, Zürich, Switzerland, pp. 128.

Meyboom P (1967). Groundwater studies in the Assiniboine River drainage basin-part II: hydrologic characteristics of phreatophytic vegetation in south-central Saskatchewan. Bull. Geol. Surv. Can. 139.

Monteith JL (1965). Evaporation and environment. In: "The state and movement of water in living organisms" (Fogg GE ed). $19^{\text {th }}$ Symp. Soc. Exp. Biol. Cambridge, UK. The Company of Biologists, pp. 205-234.

Móricz N (2010). Water balance study of a groundwater-dependent oak forest. Acta Silvatica \& Lignaria Hungarica 6: 49-66. [online] URL: http://aslh.nyme.hu/fileadmin/dokumentu$\mathrm{mok} / \mathrm{fmk} /$ acta silvatica/cikkek/Vol06-

2010/acta_vol_6_egyben_jav.pdf\#page $=47$ Nachabe M, Shah N, Ross M, Vomacka J (2005). Evapotranspiration of two vegetation covers in a shallow water table environment. Soil Science Society of America Journal 69: 492-499. - doi: 10.2136/sssaj2005.0492

National Forest Inventory Database (2000). National Forest Inventory Database. Ministry of Rural Development, Budapest, Hungary.

Otto HJ (1994). Waldokologie. UTB, Stuttgart, Germany.

Rawls WJ, Giménez D, Grossman R (1998). Use of soil texture, bulk density, and the slope of the water retention curve to predict saturated hydraulic conductivity. Transactions American Society of Agricultural Engineers 41 (4): 983-988. Ritchie JT (1972). Model for predicting evaporation from a row crop with incomplete cover. Water Resources Research 8: 1204-1213. - doi: 10.1029/WR008i005p01204

Roberts J, Rosier P (2005). The impact of broadleaved woodland on water resources in lowland UK. I. Soil water changes below beech woodland and grass on chalk sites in Hampshire. Hydrology and Earth System Sciences 9 (6) 596-606. - doi: 10.5194/hess-9-596-2005

Schilling KE (2007). Water table fluctuations under three riparian land covers, Iowa (USA). Hydrological Processes 21: 2415-2424. - doi: 10.1002/hyp.6393

Simunek J, van Genuchten MT, Sejna M (2005). The Hydrus-1D software package for simulating the one-dimensional movement of water, heat, and multiple solutes in variably-saturated media. Version 3.0, HYDRUS Software Series 1, Department of Environmental Sciences, University of California, Riverside, CA, USA, pp. 270.

Steyaert LT, Knox RG (2008). Reconstructed historical land cover and biophysical parameters for studies of land-atmosphere interactions within the eastern United States. Journal of Geophysical Research 113: D02101, pp. 27. - doi: 10.1029/ 2006JD008277

Stewart JB (1988). Modelling surface conductance of pine forest. Agricultural and forest meteorology 43 (1): 19-35. - doi: 10.1016/01681923(88)90003-2

Valente F, David JS, Gash JHC (1997). Modelling 
interception loss for two sparse eucalypt and pine forests in central Portugal using reformulated Rutter and Gash analytical models. Journa of Hydrology 190: 141-162. - doi: 10.1016 S0022-1694(96)03066-1

van Genucthen MT (1980). A closed-form equation for predicting the hydraulic conductivity of unsaturated soils. Soil Science Society of America Journal 44: 892-898. - doi: 10.2136/sssaj1980.03615995004400050002x

van Genuchten MT (1987). A numerical model for water and solute movement in and below the root zone. Research Report No 121, U.S. Salinity Laboratory, USDA, ARS, Riverside, California,
USA, pp. 221.

2004.10.006

van Genuchten MT, Leij FJ, Yates SR (1991). The RETC code for quantifying the hydraulic functions of unsaturated soils, Version 1.0. EPA Report 600/2-91/065, U.S. Salinity Laboratory, USDA, ARS, Riverside, California, USA, pp. 93.

von Hoyningen-Hüne J (1983). Die Interception des Niederschlags in landwirtschaftlichen Beständen. Schriftenreihe des DVWK 57: 1-53.

Wang Q, Adiku S, Tenhunen J, Granier A (2005). On the relationship of NDVI with leaf area index in a decidiouos forest site. Remote Sensing of Environment 94: 244-255. - doi: 10.1016/j.rse.
Wattenbach M, Hattermann F, Weng R, Wechsung F, Krysanova V, Badeck F (2005). A simplified approach to implement forest eco-hydrological properties in regional hydrological modeling. Ecological Modelling 187: 40-59. - doi: 10.1016/j.ecolmodel.2005.01.026

White WN (1932). Method of estimating groundwater supplies based on discharge by plants and evaporation from soil - results of investigation in Escalante Valley, Utah. US Geological Survey, Water Supply Paper 659-A: 1-105. 